LINGUA, Vol. 12, No. 2, September 2015

p ISSN: 1979 9411; e ISSN: 2442 238X; Web: lingua.pusatbahasa.or.id

Pusat Kajian Bahasa dan Budaya, Surakarta, Indonesia

Prihatini, Arti. 2015. Pengintegrasian Konten Budaya Lokal dalam Buku Tematik Pegangan Siswa

Kelas V Sekolah Dasar. Lingua, 12(2): 173 186.

\title{
PENGINTEGRASIAN KONTEN BUDAYA LOKAL DALAM BUKU TEMATIK PEGANGAN SISWA KELAS V SEKOLAH DASAR
}

\author{
Arti Prihatini \\ Universitas Negeri Malang \\ Email: arti_prihatini@yahoo.com
}

\begin{abstract}
This study is aimed to evaluate integration of local culture contents in the thematic textbook for the fifth grade students of Elementary School is crucial to include. This study used descriptive qualitative design. This study revealed that local culture contents incurred in the textbook comprised of: (1) internal and external local culture load, (2) development of individual and society local culture domain, (3) reading texts, istructional texts, exercises and assignments, reflection views, communication texts to students parents, and (4) implementation of local culture theories that is not yet optimally described.
\end{abstract}

Keywords: local culture contents, integration domain.

Pendidikan karakter menjadi primadona dari waktu ke waktu dalam perjalanan kurikulum yang berkembang di Indonesia. Sebut saja KTSP dan Kurikulum 2013 yang secara terstruktur mengintegrasikan nilai-nilai pendidikan karakter dalam pembelajaran. Desain pendidikan karakter pun secara teorganisasi dimulai dari jenjang sekolah dasar yang menerapkan model pembelajaran dengan buku tematik sebagai pendukungnya.

Secara tegas, Cheng (2002:33) menyatakan bahwa konten budaya lokal berkontribusi pada peningkatan mutu pendidikan. Hal itu ditempuh melalui kegiatan penyebaran dan peningkatan pengetahuan siswa tentang konten budaya lokal pada konteks lokal pula. Lebih lanjut, Unesco (2002:156-157) mengemukakan bahwa pembelajaran terpadu harus mencampurkan dan menghubungkan nilai-nilai kearifan lokal dengan wawasan global. Konsekuensi praktisnya adalah konten-konten budaya lokal harus diintegrasikan dalam materi pembelajaran, yakni dalam buku tematik siswa.

Konten budaya lokal dikatakan terintegrasi apabila ada pencampuran, penghubungan, dan penginternalisasian nilai, norma, tradisi, dan konten budaya lokal lainnya dalam pembelajaran, dalam hal ini adalah buku tematik. Hal itu sejalan dengan pendapat Cheng (2002:33) bahwa integrasi konten budaya lokal dilakukan dengan cara memasukkan norma eksplisit, nilai-nilai kearifan lokal yang penting, harapan masyarakat budaya lokal, dan juga memaparkan konsep pentingnya persatuan antarsub kultur yang ada di suatu negara.

Terdapat bermacam-macam konten budaya lokal yang dapat diintegrasikan dalam buku tematik siswa. Robinson (1988) mengemukakan konsep konten budaya lokal melalui dua kategori budaya, yaitu (a) budaya eksternal dan (b) budaya internal. Budaya eksternal adalah unsur budaya yang dapat dilihat/diamati wujudnya. Wujud budaya eksternal terdiri atas dua 
LINGUA, Vol. 12, No. 2, September 2015

p ISSN: 1979 9411; e ISSN: 2442 238X; Web: lingua.pusatbahasa.or.id

Pusat Kajian Bahasa dan Budaya, Surakarta, Indonesia

Prihatini, Arti. 2015. Pengintegrasian Konten Budaya Lokal dalam Buku Tematik Pegangan Siswa

Kelas V Sekolah Dasar. Lingua, 12(2): 173 186.

jenis, yaitu (a) berwujud perilaku, seperti bahasa, gestur, adat, dan kebiasaan; dan (b) berwujud kesusastraan, seperti folklor, seni, musik, dan artefak. Budaya internal berkaitan dengan nilai, norma, kepercayaan, pandangan hidup, dan nilai-nilai kearifan lokal lainnya.

Terdapat beberapa ranah yang dapat dijangkau oleh pengintegrasian konten budaya lokal dan wawasan kultural apa saja yang dapat dikembangkan pada setiap ranah tersebut. Periksa tabel 1.

Tabel 1. Jangkauan Ranah Budaya Lokal

\begin{tabular}{|c|c|}
\hline $\begin{array}{l}\text { Ranah Pengembangan } \\
\text { Budaya Lokal }\end{array}$ & Wawasan Kultural yang Dikembangkan \\
\hline Pengembangan individu & $\begin{array}{l}\text { - Akulturasi } \\
\text { - Sosialisasi nilai, norma, dan kepercayaan }\end{array}$ \\
\hline Pengembangan institusi & $\begin{array}{l}\text { - Sebagai pusat penyebaran dan reproduksi budaya } \\
\text { - Sebagai tempat revitalisasi dan integrasi budaya }\end{array}$ \\
\hline Pengembangan komunitas & $\begin{array}{l}\text { - Menyajikan kebutuhan kultural dalam suatu } \\
\text { komunitas }\end{array}$ \\
\hline Pengembangan masyarakat & $\begin{array}{l}\text { - Integrasi budaya dan pelestariannya } \\
\text { - Reproduksi budaya } \\
\text { - Produksi modal kultural } \\
\text { - Revitalisasi budaya }\end{array}$ \\
\hline
\end{tabular}

Sumber: Cheng (1996a dalam Cheng, 2002:32)

Konten budaya lokal itu dapat diintegrasikan dengan berbagai cara, yaitu melalui teks bacaan, teks pendukung, butir latihan, dan butir tugas. Semua itu adalah bagian-bagian buku tematik yang menjadi jalan yang dapat ditempuh untuk mengintegrasikan konten budaya lokal.

Berdasarkan fokus perhatiannya, Cheng (2002: 2-11) menyebutkan 7 teori integrasi budaya lokal ke dalam pembelajaran yang mengarah pada globalisasi, yaitu (1) teori pohon yang terfokus pada akar budaya lokal dalam proses pertumbuhan budaya untuk menghadapi masyarakat global, (2) teori kristal yang terfokus pada pengkristalan budaya lokal, (3) teori sangkar burung yang terfokus pada pembatasan ideologi untuk memproteksi budaya lokal dan menyaring budaya luar yang masuk, (4) teori DNA yang terfokus pada penggantian budaya lokal yang lemah/tidak baik dengan budaya lokal lain yang jauh lebih baik, (5) teori cendawan yang terfokus pada pencernaan wawasan global, dan (6) teori amoeba yang terfokus pada keterbukaan secara penuh terhadap wawasan global dalam proses pembelajaran yang mengarah pada globalisasi.

Pada UU No. 20 tahun 2003 tentang Sistem Pendidikan Nasional, pasal 1 tentang ketentuan umum berbunyi:

Pendidikan nasional adalah pendidikan yang berdasarkan Pancasila dan Undangundang Dasar Negara Republik Indonesia Tahun 1945 yang berakar pada nilai- 
LINGUA, Vol. 12, No. 2, September 2015

p ISSN: 1979 9411; e ISSN: 2442 238X; Web: lingua.pusatbahasa.or.id

Pusat Kajian Bahasa dan Budaya, Surakarta, Indonesia

Prihatini, Arti. 2015. Pengintegrasian Konten Budaya Lokal dalam Buku Tematik Pegangan Siswa

Kelas V Sekolah Dasar. Lingua, 12(2): 173 186.

nilai agama, kebudayaan nasional Indonesia dan tanggap terhadap tuntutan perubahan zaman.

Berdasarkan bunyi pasal tersebut, pendidikan nasional di Indonesia tergolong menerapkan dua teori sekaligus, yaitu teori pohon (tree theory) dan teori sangkar burung (birdcage theory) karena ada usaha memproteksi budaya lokal, menyaring budaya luar yang masuk ke dalam negeri, sekaligus bercita-cita mampu menghadapi perubahan zaman (globalisasi).

Berdasarkan latar belakang di atas, penelitian berjudul Pengintegrasian Konten Budaya Lokal dalam Buku Tematik Pegangan Siswa Kelas V SD ini penting dilakukan untuk menyelidiki bagaimana wajah budaya lokal ditampilkan dalam buku siswa yang merupakan sumber belajar yang mendampingi proses kognitif, psikomotor, dan afektif siswa. Rumusan masalah pada penelitian ini adalah (1) konten budaya lokal apa saja yang diintegrasikan dalam buku tematik pegangan siswa, (2) konten budaya lokal diintegrasikan dalam ranah apa saja, (3) bagaimana cara pengintegrasian konten budaya lokal itu dilakukan, dan (4) bagaimana implementasi teori pohon (tree theory) dan teori sangkar burung (birdcage theory) dalam pengintegrasian konten budaya lokal pada buku tematik pegangan siswa kelas V SD.

\section{METODE}

Penelitian ini menggunakan rancangan penelitian deskriptif kualitatif dengan ancangan teori integrasi konten budaya lokal. Objek penelitiannya adalah buku tematik pegangan siswa kelas V SD, khususnya pada tema I (Benda-benda di Lingkungan Sekitar), tema III (Kerukunan dalam Bermasyarakat) dan tema V (Bangga sebagai Bangsa Indonesia). Instrumen penelitian yang digunakan adalah lembar pengumpul data. Instrumen penelitian berbentuk tabel yang terdiri atas kolom konten budaya dan kolom data temuan. Data yang dikumpulkan adalah data verbal berupa kutipan-kutipan teks bacaan yang ada dalam buku tematik pegangan siswa. Data tersebut dikumpulkan dengan teknik dokumentasi. Setelah data terkumpul, data dianalisis berdasarkan (1) konten budaya lokal apa saja yang diintegrasi dalam teks bacaan, (2) pengintegrasian dilakukan pada ranah apa saja, dan (3) bagaimana cara pengintegrasian budaya lokal itu dilakukan. Analisis data dilakukan dalam beberapa tahap, yaitu (1) reduksi data, (2) penyajian data, serta (3) penarikan kesimpulan dan verifikasi temuan (Miles dan Huberman, 1992:16).

\section{HASIL}

Hasil penelitian ini dibagi menjadi 4, yaitu (1) konten budaya lokal, (2) ranah integrasi konten budaya lokal, (3) cara pengintegrasian budaya lokal, dan (4) implementasi teori pengintegrasian budaya lokal pada buku tematik kelas V SD yang diterbitkan oleh Kemdikbud.

\section{Konten Budaya Lokal}

Hasil penelitian konten budaya lokal yang diintegrasikan pada buku tematik kelas V SD dapat dilihat pada Tabel 2 berikut ini. 
LINGUA, Vol. 12, No. 2, September 2015

p ISSN: 1979 9411; e ISSN: 2442 238X; Web: lingua.pusatbahasa.or.id

Pusat Kajian Bahasa dan Budaya, Surakarta, Indonesia

Prihatini, Arti. 2015. Pengintegrasian Konten Budaya Lokal dalam Buku Tematik Pegangan Siswa

Kelas V Sekolah Dasar. Lingua, 12(2): 173 186.

Tabel 2. Konten Budaya Lokal dalam Buku Tematik Kelas V

\begin{tabular}{ll|}
\hline \multicolumn{1}{c}{ Aspek } & \multicolumn{1}{c}{ Temuan } \\
\hline Konten Budaya Lokal & Internal \\
& Terintegrasi dengan budaya eksternal. \\
\cline { 2 - 2 } & Eksternal \\
& $\bullet$ Perilaku: adat, \\
& $\bullet$ Kesusastraan: cerita, tari, alat musik, dan artefak. \\
\hline
\end{tabular}

Konten budaya lokal yang diintegrasikan mencakup konten budaya internal dan konten budaya eksternal. Kedua jenis konten budaya ini tidak diintegrasikan secara terpisah. Artinya, konten budaya eksternal disajikan dan konten budaya internal diintegrasikan secara terpadu pada konten budaya eksternal tersebut.

Konten budaya eksternal yang diintegrasikan adalah perilaku yang terfokus pada adat dan sastra yang mencakup cerita, tari, alat musik, dan artefak. Adat yang diintegrasikan pada umumnya berupa upacara adat yang dilaksanakan oleh masyarakat etnis tertentu dengan disertai jabaran makna filosofis yang terkandung di dalamnya.

Kesusastraan yang diintegrasikan adalah cerita, tari, alat musik, dan artefak. Cerita yang disajikan adalah cerita wayang. Budaya internal yang terintegrasi di dalamnya adalah makna cerita, karakter tokoh, dan amanat yang terkandung dalam cerita wayang.

Tari-tarian yang ditampilkan pada buku tematik siswa kelas V SD ini adalah Tari Tortor yang berasal dari Batak dan Tari Buyung yang berasal dari Sunda. Budaya internalisasi yang terintegrasi di dalamnya adalah makna tarian tersebut yang merupakan bentuk komunikasi dengan Tuhan.

Alat musik tradisional yang disajikan adalah gendang atau seruling ditampilkan bersamaan dengan teks bacaan. Hanya saja, perwujudan alat alat musik itu tidak disajikan secara utuh, artinya alat musik hanya ditampilkan dalam bentuk gambar saja tanpa penjelasan yang mendalam tentang nilai-nilai filosofis alat musik tersebut.

Artefak cukup banyak ditampilkan pada buku tematik kelas V SD ini dalam bentuk gambar atau foto, antara lain: boneka wayang, topeng, properti tarian daerah, dan perhiasan. Artefak ini ditampilkan bersamaan dengan teks, sehingga foto/gambar itu berfungsi sebagai visualisasi agar tampak konkret dan memudahkan pemahaman peserta didik. Konten budaya internal yang terintegrasi adalah simbol atau makna yang melekat pada artefak tersebut.

\section{Ranah Integrasi Konten Budaya Lokal}

Hasil penelitian ranah integrasi konten budaya lokal pada buku tematik kelas V SD dapat dilihat pada tabel 3 .

Ranah integrasi konten budaya lokal mencakup pengembangan individu dan pengembangan masyarakat. Ranah pengembangan individu mengarah pada sosialisasi nilai dan kepercayaan. Nilai dan kepercayaan itu diintegrasikan pada teks-teks yang menampilkan konten budaya lokal. Ranah ini diwujudkan dalam bentuk perenungan pada sub bagian Ayo Renungkan di buku tematik kelas V SD. Peserta didik diajak untuk merenungi suatu topik kebudayaan yang berhubungan dengan materi yang telah disampaikan. 
LINGUA, Vol. 12, No. 2, September 2015

p ISSN: 1979 9411; e ISSN: 2442 238X; Web: lingua.pusatbahasa.or.id

Pusat Kajian Bahasa dan Budaya, Surakarta, Indonesia

Prihatini, Arti. 2015. Pengintegrasian Konten Budaya Lokal dalam Buku Tematik Pegangan Siswa

Kelas V Sekolah Dasar. Lingua, 12(2): 173 186.

Tabel 3. Ranah Integrasi Konten Budaya Lokal dalam Buku Tematik

\begin{tabular}{ll|}
\hline \multicolumn{1}{c}{ Aspek } & \multicolumn{1}{c}{ Temuan } \\
\hline Ranah Integrasi Konten & Pengembangan individu \\
Budaya Lokal & - Sosialisasi nilai dan kepercayaan \\
\cline { 2 - 2 } & Pengembangan masyarakat \\
& $\bullet$ Integrasi budaya dan pelestariannya \\
& - Reproduksi budaya \\
& $\bullet$ Revitalisasi budaya \\
\hline
\end{tabular}

Konten yang tercakup pada ranah pengembangan masyarakat ini ada tiga, yaitu (1) integrasi budaya dan pelestariannya, (2) reproduksi budaya, dan (3) revitalisasi budaya. Ranah ini ada dalam buku tematik dan disajikan dengan cukup apik. Hanya saja, jumlahnya tidak banyak. Sebagian besar ranah integrasi budaya dan pelestariannya ini terinternalisasi dalam teks bacaan budaya eksternal, tetapi porsinya tetap belum mencukupi.

Pada ranah reproduksi budaya, terdapat beberapa teks yang mengangkat pentingnya penggalian budaya sekita dan pengenalan-pengenalan budaya dari daerah lain untuk menambah cakrawala pengetahuan kultural. Namun, yang menjadi catatan adalah penggalian budaya sekitar masih terpusat pada budaya masyarakat di Pulau Jawa. Konten budaya dari luar Pulau Jawa tetap dicantumkan, tetapi porsinya tidak seimbang dengan budaya di Pulau Jawa.

Pada buku tematik kelas V SD, revitalisasi budaya tampak pada teks-teks, latihan, dan tugas yang berisi penyadaran diri bagi peserta didik untuk menghidupkan budaya yang ada di Indonesia.

\section{Cara Pengintegrasian Konten Budaya Lokal}

Hasil penelitian cara pengintegrasian konten budaya lokal pada buku tematik kelas $\mathrm{V}$ SD dapat dilihat pada tabel 4 berikut ini.

Tabel 4. Pengintegrasian Konten Budaya Lokal dalam Buku Tematik

\begin{tabular}{|c|c|}
\hline \begin{tabular}{l}
\multicolumn{1}{c}{ Aspek } \\
Cara Pengintegrasian \\
Konten Budaya Lokal
\end{tabular} & Temuan \\
\hline \multirow{9}{*}{$\begin{array}{l}\text { Cara Pengintegrasian } \\
\text { Konten Budaya Lokal }\end{array}$} & Teks: \\
\hline & - Teks eksposisi \\
\hline & -Teks dialog \\
\hline & Instruksi: \\
\hline & - Instruksi pengantar \\
\hline & - Instruksi pendukung \\
\hline & Butir latihan dan tugas \\
\hline & Butir perenungan \\
\hline & Butir kerja sama dengan orangtua \\
\hline
\end{tabular}

Cara pengintegrasian konten budaya lokal ditempuh dengan memanfaatkan bagianbagian yang menyusun buku tematik siswa kelas V SD sebagaimana ditampilkan pada tabel di atas. Teks yang digunakan adalah teks eksposisi dan teks dialog yang mengangkat tema- 
LINGUA, Vol. 12, No. 2, September 2015

p ISSN: 1979 9411; e ISSN: 2442 238X; Web: lingua.pusatbahasa.or.id

Pusat Kajian Bahasa dan Budaya, Surakarta, Indonesia

Prihatini, Arti. 2015. Pengintegrasian Konten Budaya Lokal dalam Buku Tematik Pegangan Siswa

Kelas V Sekolah Dasar. Lingua, 12(2): 173 186.

tema budaya lokal. Teks instruksi pengantar berfungsi mengawali bab atau subbab yang berisi penjelasan singkat tentang konten budaya lokal yang baru akan dibahas atau yang akan dibahas secara lebih lanjut. Butir latihan dan tugas berisi pertanyaan atau tugas proyek yang berkaitan dengan konten budaya lokal. Butir perenungan berisi hal-hal yang menjadi bahan renungan siswa terkait materi yang telah disajikan dengan disertai muatan-muatan budaya lokal di dalamnya. Butir kerjasama dengan orangtua dimanfaatkan untuk mengintegrasikan konten budaya lokal dalam interaksi siswa dengan orangtua di rumah. Di antara semua cara pengintegrasian tersebut, masih terdapat beberapa kekurangan yang menyangkut pengintegrasian yang belum optimal, yaitu pada butir perenungan serta butir kerjasama dengan orangtua.

\section{Implementasi Teori Pengintegrasian Budaya Lokal}

Hasil penelitian implementasi teori pengintegrasian budaya lokal pada buku tematik kelas V SD dapat dilihat pada tabel 5 berikut ini.

Tabel 5. Implementasi Teori Pengintegrasian Budaya Lokal

\begin{tabular}{|c|c|}
\hline Aspek & Temuan \\
\hline $\begin{array}{l}\text { Implementasi Teori } \\
\text { Pengintegrasian Budaya } \\
\text { Lokal dalam Buku } \\
\text { Pembelajaran }\end{array}$ & $\begin{array}{l}\text { - Tree theory (sudah diimplementasikan tetapi } \\
\text { belum optimal) } \\
\text { - Birdcage theory (belum diimplementasikan } \\
\text { secara nyata karena tidak melihat dari sudut } \\
\text { pandang pengaruh budaya asing terhadap } \\
\text { budaya lokal) }\end{array}$ \\
\hline
\end{tabular}

Teori pengintegrasian budaya lokal yang digunakan pada buku tematik adalah teori pohon (tree theory) dan teori sangkar burung (birdcage theory). Berdasarkan teori pohon (tree theory), konten budaya lokal diintegrasikan sebagai bentuk akar budaya bangsa. Namun, bagaimana peran konten budaya lokal itu bagi pertumbuhan dan kemajuan budaya bangsa Indonesia masih belum dijelaskan, sehingga teori ini masih belum diimplementasikan secara optimal. Berdasarkan teori sangkar burung (birdcage theory), konten budaya lokal belum diimplementasikan secara nyata karena terfokus pada kedudukan budaya lokal dalam ruang lingkup nasional saja, tidak dijelaskan bagaimana pengaruh budaya asing terhadap budaya lokal yang ada di Indonesia.

\section{BAHASAN}

Pengintegrasian konten budaya lokal dalam buku tematik kelas V SD akan dijelaskan secara berurutan mulai dari (1) konten budaya lokal, (2) ranah integrasi, (3) cara pengintegrasian, dan (4) implementasi teori pengintegrasian budaya lokal.

\section{Konten Budaya Lokal}

Pengintegrasian konten budaya lokal dilakukan secara terpadu antara budaya internal dan budaya eksternal. Sesuai dengan karakter peserta didik usia sekolah dasar, perkembangan kognitifnya masih pada tahap operasi konkret, sehingga integrasi konten budaya internal ke 
LINGUA, Vol. 12, No. 2, September 2015

p ISSN: 1979 9411; e ISSN: 2442 238X; Web: lingua.pusatbahasa.or.id

Pusat Kajian Bahasa dan Budaya, Surakarta, Indonesia

Prihatini, Arti. 2015. Pengintegrasian Konten Budaya Lokal dalam Buku Tematik Pegangan Siswa

Kelas V Sekolah Dasar. Lingua, 12(2): 173 186.

dalam konten budaya eksternal adalah cara yang tepat untuk menanamkan nilai-nilai budaya lokal. Hal itu sesuai dengan pendapat Unesco (2002:157), bahwa pembelajaran terpadu harus mengintegrasikan konten budaya lokal dan hal-hal yang berbentuk material dan spiritual. Pada konteks integrasi konten budaya lokal ini, aspek material adalah budaya eksternal yang memiliki wujud yang dapat diamati dan aspek spiritual adalah budaya internal yang berupa nilai-nilai filosofis yang terkandung di dalamnya. Oleh karenanya, pelaporan hasil temuan integrasi konten budaya ini akan dijelaskan secara terpadu sebagai berikut.

\section{Perilaku}

Aspek perilaku yang diintegrasikan adalah adat. Adat mengacu pada kebiasaan yang dilaksanakan oleh kelompok kultural yang di dalamnya mengandung nilai-nilai kearifan lokal yang khas. Di situlah budaya internal masuk dalam konteks yang lebih nyata. Salah satu adat yang disajikan dalam buku tematik adalah adat seren tahun masyarakat Sunda yang merupakan sebuah ungkapan rasa syukur dan doa para petani, baik untuk tahun yang telah berlalu maupun tahun yang akan datang. Budaya internal yang masuk di dalamnya adalah pentingnya rasa syukur atas pemberian Tuhan.

\section{Kesusastraan}

Konten budaya eksternal berupa kesusastraan yang ditemukan dalam buku tematik kelas $\mathrm{V}$ adalah tarian daerah, artefak, cerita, dan alat musik. Tarian daerah yang disajikan adalah tari tor-tor suku Batak dan tari buyung suku Sunda. Tari tor-tor ada dua macam yaitu, tari tor tor sipitu cawan yang biasa digelar saat pengukuhan seorang raja dan tari tor-tor panalungan sebagai tari pembersihan yang pada zaman dulu digelar ketika masyarakat mengalami suatu permasalahan. Budaya internal yang coba dimasukkan adalah pentingnya berserah diri kepada Tuhan ketika menghadapi masalah. Hanya saja, penjelasan tentang nilai yang terkandung dalam tari tor-tor sipitu cawan tidak spesifik. Artefak menjadi barang penting dalam studi budaya, penting pula dalam studi integrasi konten budaya lokal. Cerita menjadi bagian dari budaya eksternal yang konkret dan bisa diamati. Pada buku tematik ini, cerita wayang menjadi konten budaya yang potensial untuk mengenalkan peserta didik terhadap nilai-nilai kearifan lokal. Alat musik menjadi salah satu objek budaya eksternal yang konkret bagi peserta didik.

\section{Ranah Integrasi Konten Budaya Lokal Pengembangan Individu}

Pengembangan individu menjadi ranah yang potensial untuk mengintegrasikan kontenkonten budaya lokal. Perenungan yang dilakukan peserta didik mendorong adanya introspeksi, evaluasi, dan abstraksi dirinya di dalam lingkar budaya yang ada di lingkungan sekitarnya. Hal itu sejalan dengan landasan pembelajaran terpadu yang dikemukakan Unesco (2002:156) bahwa pembelajaran terpadu hendaknya tidak hanya mengambangkan kemampuan akademik siswa saja, tetapi juga mengembangkan moral, karakter, dan kepribadian. Pada konteks pengembangan individu pada buku tematik ini, kemampuan kepribadian yang dijadikan fokus perhatian, khususnya kepribadian siswa terhadap konten budaya lokal bangsa Indonesia. 
LINGUA, Vol. 12, No. 2, September 2015

p ISSN: 1979 9411; e ISSN: 2442 238X; Web: lingua.pusatbahasa.or.id

Pusat Kajian Bahasa dan Budaya, Surakarta, Indonesia

Prihatini, Arti. 2015. Pengintegrasian Konten Budaya Lokal dalam Buku Tematik Pegangan Siswa

Kelas V Sekolah Dasar. Lingua, 12(2): 173 186.

Letaknya yang ada di akhir materi membuat perenungan ini efektif digunakan dalam misi integrasi konten budaya lokal. Konteks yang dibangun pada perenungan ini diambil dari konteks kehidupan yang dekat dengan dunia anak-anak, sehingga cocok dicantumkan dalam buku tematik. Berikut ini adalah dua contoh perenungan yang ada dalam buku tematik siswa.

(1) Ayo Renungkan

1. Apa yang telah aku pelajari hari ini?

2. Mengapa aku harus selalu melakukan perbuatan yang mencerminkan persatuan dan kesatuan di rumah?

(2) Ayo Renungkan

1. Apa yang aku pelajari hari ini?

2. Apa yang dapat aku lakukan untuk menjaga persatuan dan kesatuan dalam masyarakat?

\section{Pengembangan Masyarakat}

Pengembangan masyarakat adalah ranah yang potensial untuk mengintegrasikan konten budaya lokal, karena budaya hidup di masyarakat dan masyarakat juga yang menghidupi budaya tersebut. Budaya akan panjang umurnya jika masyarakat terus menjaga dan membesarkan budaya tersebut. Pada buku tematik kelas V SD, pengembangan ranah pengembangan masyarakat ini mengacu pada pengembangan peran dan kedudukan siswa dalam kehidupan berbudaya, khususnya budaya lokal yang ada di Indonesia. Siswa ditempatkan sebagai makhluk sosial dalam kehidupan berbudaya. Hal itu sesuai dengan landasan pembelajaran terpadu sebagaimana dikemukakan Unesco (2002:157), bahwa pembelajaran terpadu hendaknya mengembangkan potensi siswa sebagai makhluk individu dan makhluk sosial.

Pada ranah integrasi budaya dan pelestariannya, konten budaya diintegrasikan dengan berorientasi pada masa depan budaya itu sendiri, bagaimana nasib budaya di masa depan, sehingga pelestarian budaya pun diperlukan untuk menambah umur panjang budaya tersebut.

Pada ranah reproduksi budaya, konten budaya lokal yang tidak hidup subur di masyarakat digali kembali untuk menambah umur budaya tersebut. Konten budaya juga dapat direproduksi melalui pemaknaan budaya yang ada di sekitar, yakni konten budaya yang dekat dengan dunia siswa. Hal itupun telah dilaksanakan dalam buku tematik pegangan siswa kelas V SD, tetapi masih terfokus pada konten budaya lokal di Pulau Jawa. Hal itu senada dengan pendapat Samsuri (2013:10), bahwa terindikasi penyeragaman teks dan konteks tema dan materi pembelajaran untuk seluruh sekolah di daerah-daerah perkotaan maupun pedesaan, dari Sabang sampai Merauke. Hadir tokoh-tokoh dalam buku siswa seperti dicontohkan di Tema 1 kelas 1 SD yang terpusat pada suku-suku di Pulau Jawa (Javanese centered).

Pada ranah revitalisasi budaya, konten budaya dipandang dari dua sisi, yaitu masa lalu dan masa depan. Jika di masa lalu konten budaya kurang mendapatkan perhatian, revitalisasi harus dilaksanakan. Jika di masa lalu konten budaya mengalami kejayaannya, revitalisasi juga tetap perlu dilakukan untuk menjaga eksistensi budaya tersebut. Pada buku tematik kelas V $\mathrm{SD}$, revitalisasi budaya tampak pada teks-teks, latihan, dan tugas yang berisi penyadaran diri bagi peserta didik untuk menghidupkan budaya yang ada di Indonesia. Berikut ini adalah salah satu temuannya. 
LINGUA, Vol. 12, No. 2, September 2015

p ISSN: 1979 9411; e ISSN: 2442 238X; Web: lingua.pusatbahasa.or.id

Pusat Kajian Bahasa dan Budaya, Surakarta, Indonesia

Prihatini, Arti. 2015. Pengintegrasian Konten Budaya Lokal dalam Buku Tematik Pegangan Siswa

Kelas V Sekolah Dasar. Lingua, 12(2): 173 186.

(2) Baru-baru ini murid-murid Sekolah Dasar Islam Tugasku Jakarta yang tergabung dalam Sanggar Tari Ayudha tampil memikat dalam misi kesenian pada Internationales Jugend-Volkstandz Festival atau (The International Youth Folkdance Festival) ke-20 di Austria, 10-13 Juli 2013.

Saat tampil di Kota Seeboden, tanggal 11 Juli 2013, anakanak Indonesia mendapat sambutan sangat meriah dari para penonton. Bahkan, Walikota Seeboden Pak Wolgang Kliner memuji penampilan anak-anak Indonesia.

Pada data di atas, prestasi anak-anak Indonesia dalam menjaga denyut nadi budaya Indonesia ditampilkan. Respon orang asing terhadap tarian anak-anak Indonesia adalah sumbu yang menghidupkan semangat revitalisasi kebudayaan. Pada buku tematik ini, ada penggambaran revitalisasi semacam ini, tetapi belum sampai pada fungsinya untuk mendorong tindakan konkret siswa dalam lingkar revitalisasi budaya. Hal itu terbukti dari kalimat-kalimat yang cenderung deskriptif, padahal dorongan revitalisasi budaya menjadi lebih bermakna apabila juga dilengkapi dengan kalimat-kalimat yang preskriptif. Contohnya, Setelah mengetahui prestasi anak Indonesia mengharumkan nama Indonesia dalam festival tarian rakyat di Austria tersebut, apa yang dapat Kamu lakukan untuk mengharumkan nama Indonesia?

\section{Cara Pengintegrasian Konten Budaya Lokal}

Cara yang ditempuh dalam upaya pengintegrasian konten budaya lokal pada buku tematik siswa kelas V SD adalah melalui teks, instruksi, butir latihan dan tugas, butir perenungan, serta butir kerjasama dengan orangtua. Hal itu sejalan dengan pendapat Irawati (2013:158), bahwa materi pelajaran digunakan sebagai bahanatau media untuk mengembangkan nilai-nilai karakter dan budaya siswa. Pada buku tematik kelas V SD ini, konten-konten budaya lokal secara terintegrasi dalam materi pelajaran, baik yang bersifat teoretis maupun praktis. Pada aspek teori, konten budaya lokal diintegrasikan dalam bentuk teks bacaan dan teks instruksi. Pada aspek praktis, konten budaya lokal diintegrasikan dalam bentuk latihan dan tugas, butir perenungan, serta butir kerjasama dengan orangtua. Hal itu akan dijelaskan sebagai berikut.

\section{Teks}

Melalui teks, terdapat dua teks yang digunakan, yaitu teks eksposisi dan teks dialog. Kedua jenis teks ini diamanahi untuk mengusung konten budaya lokal secara konkret melalui ulasan dengan bahasa yang lugas dan dekat dengan kehidupan peserta didik. Jumlahnya cukup memadai, tetapi topiknya masih terfokus pada budaya di Pulau Jawa. Ada kontenkonten budaya dari luar Pulau Jawa, tetapi tidak sampai pada makna filosofis yang menjiwai konten budaya tersebut. Berikut ini salah satu temuannya. 
LINGUA, Vol. 12, No. 2, September 2015

p ISSN: 1979 9411; e ISSN: 2442 238X; Web: lingua.pusatbahasa.or.id

Pusat Kajian Bahasa dan Budaya, Surakarta, Indonesia

Prihatini, Arti. 2015. Pengintegrasian Konten Budaya Lokal dalam Buku Tematik Pegangan Siswa

Kelas V Sekolah Dasar. Lingua, 12(2): 173 186.

(3) Jenis tari Tor Tor beragam. Ada yang dinamakan tor tor Pangurason (tari pembersihan). Tari ini biasanya digelar pada saat pesta besar. Selanjutnya ada tari Tor Tor Sipitu Cawan (tari tujuh cawan). Tari ini biasa digelar pada saat pengukuhan seorang raja.

Terakhir, ada Tor Tor Tunggal Panaluan yang merupakan suatu budaya ritual. Biasanya digelar apabila suatu desa dilanda musibah.

Pada data di atas, tidak dijelaskan secara memadai apa itu tari pembersihan, mengapa tari tor-tor sipitu cawan digelar pada saat pengukuhan seorang raja, dan apa makna tari tor-tor sipitu cawan. Berbeda dengan teks tentang wayang yang mewakili suku Jawa, teks yang memaparkan tokoh, karakter, dan kerajinan wayang dijelaskan dengan ulasan yang sampai pada kecukupan makna.

\section{Instruksi}

Cara lain yang digunakan untuk memasukkan konten budaya lokal adalah pada instruksi. Yang dimaksud dengan instruksi ini adalah kalimat-kalimat yang berupa pengarahan (bukan materi) yang menjembatani perpindahan dari bab satu ke bab selanjutnya, dari materi satu ke materi selanjutnya, atau dari teks/materi ke latihan/tugas. Instruksi ini pada umumnya ada di bagian depan bab/subbab/materi, sehingga disebut dengan instruksi pengantar. Ada juga yang ada di tengah-tengah bab/subbab/materi, sehingga disebut dengan instruksi pendukung.

Pada buku tematik SD kelas $\mathrm{V}$, instruksi pengantar mengawal transisi dari materi sebelumnya ke materi selanjutnya yang mengandung konten budaya lokal. Begitu pula dengan instruksi pendukung yang berperan dalam menghubungkan materi atau teks yang bersifat teoritis ke latihan atau tugas yang bersifat praktis. Berikut ini adalah contoh instruksi pengantar.

(4) Dalam Pembelajaran 1, kamu telah melakukan kegiatan menuliskan produk-produk Indonesia yang dapat diekspor ke luar negeri. Produk-produk tersebut misalnya hasil tambang (minyak bumi dan tembaga) serta hasil laut (udang dan ikan). Bagaimana dengan budaya Indonesia yang kaya? Dapatkah kebudayaan kita ekspor? Tentu saja produk budaya tidak dapat diperjualbelikan. Namun, melalui duta budaya, kita dapat mempertunjukkan kebudayaan kita ke luar negeri. Kegiatan mengirim misi kebudayaan ke luar negeri telah sering dilakukan. Kegiatan itu biasanya dilakukan oleh lembaga budaya dari suatu daerah atau kota. 
LINGUA, Vol. 12, No. 2, September 2015

p ISSN: 1979 9411; e ISSN: 2442 238X; Web: lingua.pusatbahasa.or.id

Pusat Kajian Bahasa dan Budaya, Surakarta, Indonesia

Prihatini, Arti. 2015. Pengintegrasian Konten Budaya Lokal dalam Buku Tematik Pegangan Siswa

Kelas V Sekolah Dasar. Lingua, 12(2): 173 186.

\section{Butir Latihan dan Tugas}

Butir latihan dan tugas didominasi tes pengetahuan dan keterampilan, sedangkan tes untuk mengukur sikap memiliki porsi tidak sebanyak kedua jenis tes tersebut. Namun, hal itu tidak mengganggu pengintegrasian konten budaya lokal. Tes pengetahuan dan keterampilan bermanfaat dalam penambahan wawasan siswa melalui teks bacaan dan tugas bermuatan budaya, sedangkan sikap berbudaya ditampilkan dalam bentuk butir perenungan dan butir kerjasama dengan orangtua.

\section{Butir Perenungan}

Sebagaimana dijelaskan dalam ranah pengembangan individu, butir perenungan menjadi media penyadaran diri siswa tentang konten budaya lokal pada akhir bab. Butir perenungan ini dinilai menarik dan efektif karena mendorong siswa untuk meproyeksikan konten budaya tersebut ke dalam dirinya. Catatan penting untuk butir perenungan ini adalah proyek perenungan yang bervariasi dari bab satu ke bab lain akan menambah nilai guna butir perenungan ini.

\section{Butir Kerjasama dengan Orangtua}

Butir ini bermanfaat bagi siswa untuk melanjutkan pemahaman kognitif ke arah implementasi praktis dalam kehidupan sehari-hari. Cara ini dinilai efektif untuk memberikan dampak praktis konten budaya yang telah dikonsumsi pada materi yang disajikan. Terdapat beberapa catatan yang perlu digarisbawahi pada perumusan butir kerjasama dengan orangtua ini, yaitu (1) butir kerja sama tidak menunjukkan kerjasama secara konkret antara siswa dengan orangtua, (2) ditemukan butir kerjasama yang sama pada beberapa sub bab yang berbeda konsentrasi konten budaya yang diangkat, dan (3) tidak ada contoh praktis mengenai apa yang harus dikerjakan siswa. Contohnya,

(5) Kerja Sama dengan Orang Tua

Rencanakan kegiatan-kegiatanmu untuk menerapkan persatuan dan kesatuan dalam masyarakat.

\section{Implementasi Teori Pengintegrasian Konten Budaya Lokal pada Buku Tematik Pegangan Siswa Kelas V SD}

\section{Implementasi Teori Pohon (Tree Theory)}

Pada prinsipnya, teori pohon (tree theory) menganut filosofi pohon yang memiliki akarakar yang menjalar ke tanah untuk mencari sari makanan dan menjaga tegaknya batang pohon. Selain akar, pohon dapat tumbuh ke atas hingga tinggi untuk mendapatkan sinar matahari yang cukup sebagai bahan bakar fotosintesis. Berdasarkan filosofi pohon itu, pengintegrasian budaya lokal ke dalam pembelajaran adalah sebuah upaya penanaman akarakar budaya dan upaya pertumbuhan budaya lokal untuk menjawab tantangan global. Sebagaimana dikemukakan oleh Cheng (2002:11), teori pohon (tree theory) menganggap bahwa proses pengintegrasian konten budaya lokal harus berakar dari nilai-nilai dan tradisi lokal dengan tetap menyerap pengetahuan global yang bermanfaat dan relevan dalam 
LINGUA, Vol. 12, No. 2, September 2015

p ISSN: 1979 9411; e ISSN: 2442 238X; Web: lingua.pusatbahasa.or.id

Pusat Kajian Bahasa dan Budaya, Surakarta, Indonesia

Prihatini, Arti. 2015. Pengintegrasian Konten Budaya Lokal dalam Buku Tematik Pegangan Siswa

Kelas V Sekolah Dasar. Lingua, 12(2): 173 186.

penumbuhkembangan konten budaya lokal secara utuh, baik di dalam maupun di luar proses pembelajaran.

Pada buku tematik siswa, prinsip tree theory diterapkan melalui upaya pengintegrasian konten budaya lokal -baik internal maupun eksternal- sebagai bentuk penanaman wawasan budaya lokal agar mengakar dalam benak siswa. Namun, akar budaya yang coba diintegrasikan tidaklah menyebar secara merata, karena cenderung terfokus pada konten budaya lokal di Pulau Jawa. Prinsip penumbuhkembangan budaya lokal ke kancah global diintegrasikan dalam buku tematik kelas V SD, tetapi jumlahnya tidak banyak. Jadi, dapat disimpulkan bahwa teori pohon ini sudah diterapkan dalam proses pengintegrasian konten budaya lokal pada buku tematik, tetapi masih belum optimal.

\section{Implementasi Teori Sangkar Burung (Birdcage Theory)}

Pada prinsipnya, teori sangkar burung (birdcage theory) menganut filosofi sangkar burung. Alasan mengapa burung dipelihara dalam sangkar adalah agar burung itu aman dari binatang lainnya, agar burung itu tidak lepas dan terbang bebas meninggalkan sang pemilik. Oleh karenanya, pengintegrasian budaya lokal yang berbasis birdcage theory ini cenderung memberikan perlindungan dan penyaringan gangguan dari luar agar budaya lokal itu tetap ada dalam masyarakat. Sebagaimana diungkapkan Cheng (2002:12), di era globalisasi ini dunia pendidikan membutuhkan konten budaya lokal untuk menyaring konten budaya asing yang masuk dan melindungi budaya lokal dari pengaruh negatif yang berpotensi menggeser budaya lokal tersebut.

Pada buku tematik pegangan siswa, teori sangkar burung (birdcage theory) ini belum diimplementasikan secara nyata. Pengaruh era globalisasi terhadap budaya lokal tidak diulas/dibahas. Perlindungan terhadap budaya lokal hanya dilihat dari sudut pandang ke dalam, belum sampai pada sudut pandang pengaruh negatif budaya luar terhadap budaya lokal Indonesia. Padahal, pentingnya budaya lokal ini secara tegas dijelaskan Unesco (2002:157) bahwa pembelajaran terpadu harus mengintegrasikan konten budaya lokal dan konten budaya global, nilai-nilai, dan keterampilannya untuk mengembangkan pribadi peserta didik sebagai warga negara dan warga dunia yang baik.

\section{SIMPULAN}

Berdasarkan penelitian yang telah dilakukan, terdapat beberapa kesimpulan yang dapat dirumuskan. Pertama, konten budaya lokal yang diintegrasikan dalam buku tematik pegangan siswa kelas V SD mencakup budaya internal dan budaya eksternal yang saling terintegrasi. Kedua, pengintegrasian konten budaya lokal pada buku tematik pegangan siswa kelas V dilakukan melalui beberapa cara, yaitu (1) aneka jenis teks bacaan, yaitu (teks eksposisi dan teks dialog); (2) instruksi, baik instruksi pengantar maupun instruksi pendukung; (3) butirbutir latihan dan tugas, dan (4) butir perenungan, dan (5) butir kerjasama dengan orangtua. Ketiga, ranah integrasi konten budaya lokal mencakup ranah pengembangan individu dan ranah pengembangan masyarakat. Keempat, konten budaya lokal diintegrasikan melalui lima cara, yaitu melalui (1) aneka jenis teks, (2) instruksi pengantar dan instruksi pendukung, (3) butir latihan dan tugas, (4) butir perenungan, dan (5) butir kerjasama dengan orangtua. Kelima, teori pohon (tree theory)telah diimplementasikan dalam upaya pengintegrasian 
LINGUA, Vol. 12, No. 2, September 2015

p ISSN: 1979 9411; e ISSN: 2442 238X; Web: lingua.pusatbahasa.or.id

Pusat Kajian Bahasa dan Budaya, Surakarta, Indonesia

Prihatini, Arti. 2015. Pengintegrasian Konten Budaya Lokal dalam Buku Tematik Pegangan Siswa

Kelas V Sekolah Dasar. Lingua, 12(2): 173 186.

budaya lokal dalam buku tematik siswa, tetapi masih belum optimal, sedangkan teori sangkar burung (birdcage theory) belum diimplementasikan secara nyata karena pengintegrasian budaya lokal hanya terfokus pada proteksi di dalam tanpa melihat kemungkinan pengaruh negatif budaya luar.

\section{SARAN}

Berdasarkan uraian di atas, terdapat beberapa saran yang akan disampaikan. Pertama, guru kelas di sekolah dasar disarankan memanfaatkan buku tematik dengan baik untuk menanamkan pendidikan karakter, khususnya yang berkaitan dengan konten-konten budaya lokal. Kedua, mahasiswa Pendidikan Bahasa dan Sastra Indonesia dapat mengembangkan wawasan tentang konten budaya lokal melalui telaah buku teks atau melalui forum diskusi.

\section{DAFTAR RUJUKAN}

Cheng, Y. C. 2002. Fostering Local Knowledge and Wisdom in Globalized Education:

Multiple Theories. Artikel disajikan pada The 8th International Conference on

"Globalization and Localization Enmeshed: Searching for a Balance in Education",

Bangkok, 18-21 November 2002, (Online),

(https://home.ied.edu.hk/ yccheng/doc/speeches/18-21nov02.pdf), diakses 8 Desember 2014.

Irawati, R.P. 2013. Bahan Ajar Bahasa Indonesia Tematik Berkarakter dan Berbudaya dengan Sastra Anak bagi Siswa SD. Varia Pendidikan, Vol. 25, No. 2:157-171, (Online), (https://publikasiilmiah.ums.ac.id), Diakses 30 September 2014.

Kemdikbud. 2014a. Benda-benda di Lingkungan Sekitar: Buku Tematik Terpadu Kurikulum 2013 Tema 1 Buku Siswa SD/MI Kelas V. Jakarta: Kementerian Pendidikan dan Kebudayaan.

Kemdikbud. 2014b. Kerukunan dalam Bermasyarakat: Buku Tematik Terpadu Kurikulum 2013 Tema 3 Buku Siswa SD/MI Kelas V. Jakarta: Kementerian Pendidikan dan Kebudayaan.

Kemdikbud. 2014c. Bangga sebagai Bangsa Indonesia: Buku Tematik Terpadu Kurikulum 2013 Tema 5 Buku Siswa SD/MI Kelas V. Jakarta: Kementerian Pendidikan dan Kebudayaan.

Miles, M. B. dan Huberman, A. M. 1992. Analisis Data Kualitatif. Jakarta: Universitas Indonesia Press.

Robinson, G. 1988. Cross Cultural Understanding. Hemel Hempstead, UK: Prentice Hall International.

Samsuri. 2013. Kebijakan Pembelajaran Tematik Terpadu Kurikulum 2013. Yogyakarta: Program Studi Pendidikan Dasar Program Pascasarjana Universitas Negeri Medan.

Undang-undang RI No. 20 tahun 2003 tentang Sistem Pendidikan Nasional. Dokumentasi dan Informasi Hukum Badan Pemeriksa Keuangan Republik Indonesia, (Online), (http://jdih.bpk.go.id), diakses 6 September 2014.

Unesco. 2002. A Holistic and Integrated Approach to Values Education for Human Development. Bangkok: Unesco Asia and Pacific Regional Bureau for Education. 
LINGUA, Vol. 12, No. 2, September 2015

p ISSN: 1979 9411; e ISSN: 2442 238X; Web: lingua.pusatbahasa.or.id

Pusat Kajian Bahasa dan Budaya, Surakarta, Indonesia

Prihatini, Arti. 2015. Pengintegrasian Konten Budaya Lokal dalam Buku Tematik Pegangan Siswa

Kelas V Sekolah Dasar. Lingua, 12(2): 173 186. 